\title{
MEKANISME HUKUM DI DALAM MASYARAKAT
}

\section{Oleh: Nurbaedah}

\begin{abstract}
Abstrak
Tatanan hukum yang dibuat harus atas dasar kesadaran dan kemauan, keinginan setiap anggota masyarakat, agar mekanisme hukum dapat berjalan berdasarkan tatanan karena tatanan itu dibangun dan dibentuk oleh masyarakat itu sendiri. Barang-barang yang ada tentunya anggota masyarakat harus patuh mengikutinya dan adanya keseimbangan dalam setiap hubungan dengan mekanisme tersebut dan masyarakat tidak boleh menentang kehidupan masyarakat yang berlaku. Aturan yang dibentuk misalnya tidak efektif maka akan timbul gejala-gejala yang sebaliknya maknanya akan membingungkan kestabilan penegakan hukum. Oleh karena itu penetapan peraturan perundang-undangan yang dibentuk masyarakat sendiri harus dapat diterima dan harus ditaati
\end{abstract}

Kata Kunci: aturan, tatanan, mekanisme

\begin{abstract}
Law orders created shall on the basis of awareness and will, desire every society member, so that law mechanism can be run by order because that orders is woke up and formed by society itself. Goods which have of course society member have to be obedient adhering him and existence of balance in every relation with that mechanism and society may not oppose against life of society going into effect. formed Rule for example is not effective hence will arise symptoms which on the contrary its meaning will confuse stability of is straightening of law. Because of that's stipulating of orders of law formed society itself have to earn to be accepted and have to obey.
\end{abstract}

Keywords: mechanism, order, rules

\section{PENDAHULUAN}

A. Latar Belakang

Sebagaimana yang telah kita ketahui bahwa keberadaan hukum sangat penting dalam pergaulan bermasyarakat di mana hal-hal atau peristiwa yang konkret banyak terjadi dalam kehidupan bermasyarakat, sehingga menyebabkan timbulnya hukum yang bersifat dinamis dan konsisten. Rangkaian yang terdiri dan timbul dari keberadaan di tengah-tengah masyarakat itu secara tidak langsung timbul sebagai kaidah-kaidah atau norma-norma yang hidup dan tumbuh dikalangan masyarakat. Beberapa lapisan yang ada di masyarakat itu menimbulkan pelbagai kaidah dan norma-norma yang timbul dan berkembangan 
serta tetap dijalankan dilapisan masyarakat itu sendiri.

Timbulnya kaidah hukum yang ada ditengah-tengah masyarakat itu telah dijadi kan tolak ukur sebagai salah satu sumber hukum yang mana telah dikemukakan oleh Prof. S.C Kansil, SH "Sumber hukum yaitu: segala apa saja yang menimbulkan aturan-aturan yang mengatur tingkah laku manusia dalam hidup bermasyarakat, yaitu aturan-aturan kalau dilanggar dapat dikenai sanksi yang tegas dan nyata". Dari salah satu sumber hukum tersebut dapat kita kaji bahwa hukum adalah yang mengatur masyarakat dalam perilaku sehari-hari, bukan masyarakat mengatur hukum.

\section{Masalah hukum di dalam masyarakat}

Dengan meninjau beberapa aspek kehidupan bermasyarakat perlu kita menelusuri kehidupan dimasyarakat kita saling berbeda-beda, hal ini disebabkan timbulnya rasa kebiasaan yang menyebabkan suatu tradisi dari lingkungan suatu daerah tertentu. Sehingga antara satu daerah dengan daerah yang lain sangat jauh berbeda dalam melaksanakan kegiatan hukumnya, misalnya dalam menjalankan hal-hal yang dianggap sangat sakral disini masih adanya ketentuan norma-norma yang tumbuh didalam masyarakat, jadi jika kita menghendaki adanya perbuatan hukum, maka dari factor sosiologis yang sangat menentukan yaitu dari aspek kehidupan seseorang dimana mereka yang tinggal di suatu daerah tertentu.

Mengingat bahwa negara kita adalah negara hukum yang pasti segala permasalahan yang timbul dalam kehidupan masyarakat, hendaknya diselesaikan dengan jalan hukum, yang mana dalam menangani masalah keberadaan hukum ditengah-tengah masyarakat itu perlu adanya kepastian hukum. Dengan demikian masalah yang mungkin timbul dalam kehidupan kita dapat teratasi dengan jalan adat kita yaitu musyawarah untuk mufakat

\section{Hubungan antara hukum dengan masyarakat}

Keterkaitan hukum dengan masyarakat secara nyata telah kita ketahui dimana manusia atau masyarakat telah diatur oleh hukum sejak manusia itu lahir, bahkan masih dalam kandungan asal lahir dalam keadaan hidup sampai manusia tersebut meninggal dunia. Manusia tidak akan lepas dari hukum karena manusia secara logika dari kehidupan sehari-hari diatur oleh hukum, baik hubungan antara seseorang dengan seseorang, seseorang dengan badan hukum dan lain sebagainya.

Hubungan bilateral antara hukum dengan masyarakat ini mengakibatkan suatu tatanan atau struktural dalam membahasa masalah-masalah yang ada dalam masyarakat. Sebagaimana masyarakat di Indonesia mempunyai beberapa segi aspek kehidupan yang mana aspek tersebut telah ada sejak zaman nenek moyang kita, yaitu kita ambil secara garis bawah misalkan dari tradisi atau adat dalam hal perkawinan, dimana masyarakat kita telah melihat hal tersebut adalah hal yang sakral. Lapisan-lapisan kelompok masyarakat ini menimbulkan beberapa pertanyaan apakah dapat diklasifikasikan mengenai masalah perkawinan atau cara sahnya dalam perkawinan .

Dengan mengetahui lebih jelas sistem kesadaran hukum dimasyarakat kita, maka hukum hendaklah berada di tengah-tengah masyarakat kita, maka 
hukum mana dari berbagai lapisan tersebut secara jelas dapat diketahui hukum sebagai penengah didalam kehidupan bermasyarakat. Secara garis besar masyarakat kita mengerti atau masih awam terhadap masalah-masalah yang timbul yang mana masalah tersebut harus berurusan dengan hukum. Banyak yang telah diketahui bahwa timbulnya beberapa lapisan masyarakat mengakibatkan tindakan dari pelaksanaan hukum untuk menjadi penegak hukum perlu adanya tindakan secara proporsional.

\section{B. PERMASALAHAN}

Bagaimanakah hukum harus diterapkan dengan jelas dan konkret sebagai salah satu social control ditengah-tengah masyarakat? Negara kita adalah negara yang sedang berkembang dan selalu mengalami perubahan-perubahan dalam kehidupan sehari-hari, yang mana penerapan hukum harus ditegakkan sebagaimana yang telah ada sejak zaman Belanda

1. Penerapan hukum dalam masyarakat

Kinerja hukum yang bagaimanakah yang timbul dalam pelaksanaan hukum di masyarakat kita, yang mana dari zaman ke zaman selalu mengalami perubahan aspek sosiologis sehingga membutuhkan kepastian hukum dalam mengatasi segala persoalan. Apakah perlu diadakannya unifikasi hukum agar masyarakat sadar akan hukum? Hal ini dapat kita lihat melalui beberapa aspek kehidupan di masyarakat yang mana dari kelompok perseorangan juga membutuhkan perlindungan hukum, sehingga dari beberapa segi hukum tersebut dapat diunifikasikan dan sekarang ini telah ditegakkan sebagai penerapan hukuman yaitu hukum pidana.

2. Sistematika dan mekanisme hukum yang ada didalam masyarakat

Hukum mempunyai beberapa segi yang mana perlu adanya tatanan yang dapat memperlakukan atau mengatur kehidupan di masyarakat agar mendapat kepastian hukum dan hidup yang tentram dan damai. Cara-cara atau sistematis hukum itu hendaknya perlu di telaah oleh seluruh lapisan masyarakat yang aturanaturan mengenai perintah, larangan dan sanksi hukum tersebut perlu adanya kejelasan disemua kalangan, tidak memandang itu siapa atau siapa saja.

Keadaan inilah yang membuat berbagai pertanyaan apakah hukum itu untuk kalangan menengah keatas, kebawah atau sebagainya. Dimana dari berbagai macam bentuk peristiwa yang timbul dewasa ini membutuhkan kejelian di bidang hukum, seperti banyaknya kasus-kasus misalkan penggusuran, penutupan kasus korupsi, kasus pembunuhan dan lain sebagainya. Tuntutan-tuntutan inilah yang membutuhkan sistematika dan mekanisme hukum yang ada pada saat ini. Sistematika dan mekanisme hukum dalam masyarakat sekarang ini hendaklah perlu adanya suatu perubahan sosial yang direncanakan, perubahan tersebut dibarengi dengan pengendalian serta pengawasan dari pelapor perubahan tersebut

\section{PEMBAHASAN}

1. Terjadinya Hukum Sebagai Kerangka Hidup di Masyarakat

Dengan melihat uraian tersebut diatas maka telah terjadilah suatu konsepsi-konsepsi di bidang hukum yang mana telah disusun dan diatur demi 
terlaksananya ketentuan ataupun peraturan untuk menentramkan kehidupan bermasyarakat, dengan demikian tercapainya suatu konsep hukum yang dibuat oleh lembaga-lembaga tersebut memang mengalami banyaknya hambatan yang dikarenakan banyaknya perbedaan kelompok atau struktur kehidupan masyarakat yang sangat berbeda-beda dengan demikian lembaga perundangundangan membuat suatu aturan-aturan tersebut berlandaskan pada asas-asas keadilan di masyarakat itu sendiri menginginkan atau membutuhkan keadilan. Hukum yang terjadi pada dewasa ini mempunyai beberapa tujuan yang mana telah dikemukakan oleh Drs. C.ST Kansil, SH, "Hukum bertujuan untuk menjamin adanya kepastian hukum dalam masyarakat dan hukum itu sendiri harus pula bersendikan pada keadilan, yaitu asas-asas keadilan dari masyarakat.

Dengan melihat tujuan dari pada hukum itu sendiri maka kita tinjau bahwa salah satu kerangka hidup agar terhindar dari segala macam pertikaian dalam kehidupan masyarakat sehingga mampu mengatasinya adalah hukum. Maka dibuatlah suatu konsep bahwa hukum yang ada dinegara kita yaitu Indonesia dilihat dari segi bentuknya dibedakan antara hukum tertulis dan hukum tidak tertulis. Dari konsep-konsep tersebut diatas maka lembaga-lembaga berwenang telah menciptakan beberapa hal mengenai hukum yang - mana dasar dari pada konsepsi tersebut terletak pada dasar asas-asas masyarakat itu sendiri yang bertujuan untuk menjamin kepastian hukum.

\section{Hukum Tertulis}

Dari uraian tersebut maka salah satu yang dibuat oleh lembaga-lempaga perundangan yang disusun dan diatur untuk menciptakan suatu kepastian hukum adalah undang-undang, Maka segala peraturan yang dibuat lembaga tersebut dicantumkan dalam belbagai peraturan-peraturan. lnilah yang dimaksud dengan hukum tertulis dimana hukum tertulis dapat dibedakan menurut bentuknya yaitu hukum tertulis yang dikodifikasikan seperti halnya hukum pidana, yang tercantum dalam Kitab undang-undang pidana dan Kitab Undang-undang Acara Pidana. Kitab Undang-undang tersebut diberlakukan ke semua kalangan diseluruh Indonesia yang artinya semua bentuk dari Kitab Undang-undang Hukum Pidana mencakup luas dan wajib dipatuhi di seluruh wilayah Republik Indonesia.

Hukum tertulis yang tidak dikodifikasikan misalkan kitab undangundang Hukum Perdata, ini disebabkan adanya sedikit perbedaan dimana bangsa Indonesia mempunyai beberapa pulau yang berbeda-beda adat istiadatnya. Hukum tertulis yang tidak dikodifikasikan ini menimbulkan suatu konsepsi tersendiri, dengan demikian timbullah peraturan tersendiri dari hukum tertulis, misalnya dalam hal perkawinan, yang mana mempunyal asas monogamy dimana di Indonesia mempunyai beberapa budaya, tradisi dan beberapa agama. Munculnya beberapa agama di Indonesia dalam menangani hal perkawinan membuat beberapa keputusan yang tidak dapat langsung dijalankan oleh semua kalangan, karena sumber dari pada hukum untuk mengatasi hal yang menyangkut perkawinan tersebut tidak berdasarkan dari Kitab Undang-undang Hukum Perdata. Hal ini timbul karena dari masyarakat yang beragama Islam mengikuti dasar hukum yang ditetapkan oleh dasar dari 
hukum Islam tersebut dan dalam pelaksanaannya dijalankan oleh peraturan pemerintah dalam hal ini dilaksanakan oleh Departemen Agama yang berdasarkan Undang-undang Nomor 1 Tahun 1974, sedangkan dari agama selain Islam berdasarkan Catatan sipil yang diberlakukan berdasarkan kitab undang-undang hukum perdata yang dicantumkan olehpemerintah.

\section{Hukum Tidak Tertulis}

Selain konsepsi yang dibuat oleh lembaga perundangan di masyarakat juga mengenal dan menyakini terhadap hukum yang ada di kehidupan masyarakat tersebut. Dimana hukum tersebut tidak dicantumkan ke dalam suatu peraturan tertentu akan tetapi dilaksanakan oleh sebagian masyarakat karena terdapat unsur kepercayaan yang mana berlandaskan pada moral dari masing-masing orang. Masyarakat lebih mengenal pada hukum adat atau hukum kebiasaan, hukum memang tidak ada dalam perundang-undangan tetapi masih diyakini oleh sebagian lapisan masyarakat karena hukum tersebut berlandaskan pada normanorma atau kaidah-kaidah di dalam masyarakat.

Mereka percaya pada hukum adat atau kebiasaan tersebut karena juga dapat mengatur atau menjadi landasan bagi kehidupan mereka sehari-hari. Kepercayaan mereka menimbulkan suatu tradisi dan sampai sekarang ini masih berlaku pada sebagian lapisan masyarakat kita. Meskipun hukum kebiasaan tidak tercantum didalam peraturan tersendiri akan tetapi pemerintah tetap menjalankan hukum tersebut karena dilihat secara tidak langsung menimbulkan suatu kebudayaan yang tidak dapat dimiliki oleh negara lain, hal ini dibuktikkan dengan adanya berbagai persoalan atau masalah yang menyangkut tradisi atau budaya dari daerah masing-masing dimana tradisi tersebut sangat berbeda-beda. Hukum adat mempunyai sifat komunal yang kuat artinya manusia menurut hukum adat merupakan makhluk dalam ikatan kemasyarakatan yang erat, rasa kebersamaan tersebut meliputi seluruh lapangan hukum adat. Hukum adat mempunyai corak magisch religius yang berhubungan dengan pandangan hidup alam Indonesia. Hukum adat diliputi oleh fikiran serba konkrit dimana hukum adat sangat m'emperhatikan banyaknya dan berulangulang hubungan- hubungan hidup yang kongkrit. Hukum adat mempunyai sifat yang sangat visual, artinya hubungan-hubungan hukum dianggap hanya terjadi oleh karena ditetapkan dengan suatu ikatan yang dapat' dilihat.

\section{KESIMPULAN}

Dari berbagai uraian tersebut diatas dapatlah kita pahami bahwa hubun'gan antara perubahan-perubahan sosial dengan hukum menonjolkan segi dinamika dari suatu masyarakat yang dapat dikatakan merupakan ciri yang tetap dari setiap masyarakat. Di lain pihak, hukum sebagai gejala sosial merupakan suatu sarana untuk mempertahankan serta menjaga adanya ketertiban. Khususnya bagi negara-negara yang lahir melalui suatu perjuangan kemerdekaan atau revolusi hukum seringkali dianggap sebagai lambang status quo, namun negara-negara yang muda sebut saja Indonesia merupakan salah satu contoh pada dewasa ini sedang dalam mengalami proses pembangunan yang mempunyai ciri berupa suatu proses perubahan. Perubahan tidak selamanya 
menghasilkan keadaan-keadaan yang positif, apa lagi bila proses tersebut tidak berjalan secara teratur.

Hukum berperan untuk menjamin bahwa perubahan-perubahan tadi terjadi dengan teratur dan tertib, walaupun demikian sebagai alat untuk-mengubah masyarakat dan menjamin ketertiban proses perubahan tersebut, maka hukum mempunyai batas-batas dan kondisi-kondisi tertentu. Apabila batas-batas dan kondisi-kondisi tersebut diperhatikan, dimengerti dan diterapkan, maka dapatlah diperkirakan bahwa penggunaan hukum sebagai alat mempunyai harapan-harapan yang positif dalam mengubah masyarakat serta menciptakan masyarakat yang tertib dalam mendukung pembangunan. Apakah harapan-harapan tersebut akan terwujud atau tidak, harus dikembalikan kepada para pelopor perubahan atau pembangunan yang mempergunakan tersebut sebagai suatu sarana. Dengan melihat berbagai masalah sosial dan perubahan-perubahan sosial yang timbul di dalam kehidupan bermasyarakat, maka setiap masyarakat haruslah mempunyai kesadaran akan adanya tertib hukum, karena dengan adanya tertib hukum maka perubahan-perubahan dari segi dinamika masyarakat menimbulkan suatu dorongan pembangunan dari segala bidang yang dibentuk oleh pelopor perubahan-perubahan sosial tersebut.

Akan tetapi dalam menindak berbagai masalah yang timbul di dalam kehidupan bermasyarakat perlu adanya tindakan proporsional dari pelopor penegak hukum, sehingga mekanisme hukum yang ada didalam masyarakat mempunyai suatu wadah atau kepercayaan bagi pelopor penegak hukum dalam mengatasi tertib hukum. Gejolak yang timbul dewasa ini mengakibatkan suatu perubahan sosial dimana perubahan tersebut memerlukan suatu konsepsi yang harus diiakukan oleh penegak hukum secara konstitusional dalam menanggapi berbagai persoalan sehingga tidak terjadi suatu kendala dalam melakukan atau menjalankan pembangunan di segala bidang.

\section{DAFTAR PUSTAKA}

Aubert, Vilhel (ed). Sociology of Law. Middlesex. Penguin Boooks. 1969

C.S.T. Kansil. Pengantar Ilmu Hukum. Balai Pustaka, Jakarta, 1992

Fruend, Julien. The Sociology of Marx Weber. New York. Vintage Books. 1969

Moeljatno. Kitab Undang-undang Hukum Pidana Cet. II. Bumi Aksara, Jakarta. 1990

Soerjono Soekanto. Pokok-pokok Sosiologi Hukum. Rajawali Press. Jakarta. 1988

Subekti, R. Dan Tjitrosudibio. Kitab Undang-undang Hukum Perdata. Pradya Pramita. Jakarta. 1989

Tjipto Raharjo SH, Permasalahan Hukum di Indonesia. Alumni. 1979 